\title{
Thermoanalytical study of praziquantel-loaded PLGA nanoparticles
}

\author{
Rubiana Mara Mainardes*, Maria Palmira Daflon Gremião, Raul Cesar Evangelista \\ Departamento de Fármacos e Medicamentos, Faculdade de Ciências Farmacêuticas de Araraquara, Universidade \\ Estadual Paulista "Júlio de Mesquita Filho" - UNESP
}

*Correspondence:

R. M. Mainardes

Departamento de Fármacos e

Medicamentos da Faculdade de

Ciências Farmacêuticas-UNESP

Rod. Araraquara-Jáú Km 1,

14801-902 - Araraquara - SP, Brazil

E-mail: mainardes@fcfar.unesp.br
Polymeric nanoparticles have received great attention as potential controlled drug delivery systems. Biodegradable polymers has been extensively used in the development of these drug carriers, and the polyesters such as polylactic acid, polyglycolic acid and their copolymers as poly-lactide-co-glycolide are the most used, considering its biocompatibility and biodegradability. Thermal analysis techniques have been used for pharmaceutical substances for more than 30 years and are routine methods for screening drugexcipient interactions. The aim of this work is to use thermal analysis to characterize PLGA nanoparticles containing a hydrophobic drug, praziquantel. The results show that the drug is in an amorphous state or in disordered crystalline phase of molecular dispersion in the PLGA polymeric matrix and that the microencapsulation process did not interfere with the chemical structure of the polymer, mantaining the structural drug integrity.
Uniterms

- Nanoparticles

- Praziquantel

- PLGA

- DSC

- TG-DTA

- Infrared spectroscopy

\section{INTRODUCTION}

Nanoparticles are considered one of the most promising dosage forms as potential formulations for sitespecific drug delivery system including drug targeting (Mainardes, Silva, 2004; Hans, Lowman, 2002). Colloidal polymeric particles used as drug carriers can be made of artificial or natural polymers, which must be biocompatible (Soppimath et al., 2001; Gorner et al., 1999). In the past two decades, many works have been carried out in order to apply biocompatible and/or biodegradable polymers in drug delivery systems (Jain, 2000).

Nanoparticles are a collective name for nanospheres and nanocapsules. Nanospheres have a matrix type structure, where active compounds can be adsorbed on their surface, entrapped or dissolved into the matrix. Nanocapsules have a polymeric shell and an inner core. In this case, the active substances are usually dissolved in the core, but may also be adsorbed on their surface (Allemann et al., 1998; Panyam, Labhasetwar, 2003).

Although a number of different polymers have been investigated for formulating biodegradable nanoparticles, polymers of poly(L-lactic-acid) (PLA) and their copolymers with glycolic acid (PLGA) have been extensively used in controlled drug delivery systems. The lactide/glycolide polymers chains are cleaved by hydrolysis to form natural metabolites (lactic and glycolic acids), which are eliminated from the body through the citric acid 
cycle. PLGA provides a wide range of degradation rates, from months to years, depending on its composition and molecular weight (Mainardes, Evangelista, 2005; Uhrich et al., 1999; Vert et al., 1998; Anderson, Shive, 1997; Burkersroda et al., 2002).

Aliphatic polyesters are polymers of the poly $(\alpha-$ hidroxy) acids class, one of the polymers families more attractive and promising, because their members are biocompatible and bioresorbable and could be used in several applications in the medicinal area (Iannace et al., 1994). The presence of the ester linkage makes these polymers hydrolytically unstable, this means that they can be degraded when in contact with the corporal fluids, resulting in products that are reabsorbed by the organism, as part of the carbohydrates metabolism (Beiser, Kanat, 1990). In the last years, the biodegradable polymers have gained a growing importance in the medical area. They have been used in a wide number of applications in the human body, such as surgical sutures, controlled drug release systems, artificial skins, guides for nerves, veins and artificial arteries and orthopedic devices (Langer et al., 1990). Usually, for polymers to be used as biomaterials, it is necessary to satisfy a series of requirements, not always found in only one polymer. The degradation rate of the aliphatic polyesters in vitro and in vivo was investigated by several authors (Holland, Yasin, 1986; Vert, Garreau, 1991; Dumitriu, 1996; Lindhardt, 1998). It is known that the molar mass, polydispersion, crystalline degree, morphology, thermal history and chemical structure of the polymers are factors that influences considerably the degradation rate (Dumitriu, 1996). Polymers with lower molar mass degrade faster than those with higher molar mass (Lindhardt, 1998) and the branched polymers degrade faster than the linear ones. However, the mechanism of the degradation is not totally understood.

When working with biodegradable polymer systems, the selection of appropriate techniques of characterization is an important step to assure a reproducible and effective product. Biodegradable polymers have several physical and chemical characteristics, such as molecular mass average and distribution, glass transition and/or melting temperatures, monomer ratios and sequencing for copolymers. All these properties can influence the physical behavior of raw polymers (Hausberg, Deluca, 1995).

The mobility of a polymeric chain determines the physical characteristics of the final product. The mobility is a function of atoms agitation in the molecules, being directly proportional to the temperature. Therefore, the knowledge of the physicochemical characteristics of a polymer is fundamental to understand its thermomechanical performance (Canevarolo, 2002).

When polymers are used as controlled drug delivery systems, additional qualities, such as surface area, bulk density, surface morphology and particle size are included and may affect both degradation and drug release from the polymeric system. This requires analysis of these properties for a complete understanding and eventual prediction of the system's behavior (Hausberg, Deluca, 1995).

Thermoanalytical methods, such as DSC and DTA, are of great usefulness for polymers analysis, and they have been also used to investigate interactions between polymer and drugs in several formulations of micro- and nanoparticles (Gamisans et al., 1999; Calvo et al., 1996). Useful information can be obtained regarding the crystalline morphology of the polymer and the state of solid or molecular dispersion of the associated drug to these polymeric systems (Magenhein, Benita, 1991; Schaffazick et al., 2003). DSC analyses have been also used to study the intermolecular interactions between drugs and pharmaceutical adjuvants. They are of great usefulness in pre-formulation studies, because information about the physical potential or chemical incompatibilities between drug and adjuvants can be obtained (Marini et al., 2003). It is also possible to investigate chemical reactions, such as polymerization and degradation. In particular, DSC allows a rapid evaluation of possible incompatibilities by revealing changes in the appearance, shift or disappearance of melting or other endothermic and/or exothermic processes, and/or variations in the corresponding enthalpies reactions (Schaffazick et al., 2003). Additional information regarding the effects of storage at high temperatures can also be obtained (Araujo et al., 2003). The development of new dosage forms is facilitated by the use of thermal methods for characterization of pharmaceutical preparations with the direct application to the quality control (Ford, Timmins, 1986).

Thus, the goal of this work was to apply thermal analysis to characterize biodegradable nanoparticles containing the model drug praziquantel (PRZ), an antischistosoma drug.

\section{MATERIAL AND METHODS}

\section{Materials}

The polymer studied was: Poly(D,L-lactide-coglycolide) (PLGA), with a copolymer ratio of DL-lactide to glycolide of 50:50 $\left(\mathrm{M}_{\mathrm{w}} 40,000-100,000 \mathrm{~g} / \mathrm{mol}\right)$ (Sigma Chemical CO, USA). The surfactant used was poly(vinyl alcohol) (PVA) (Sigma Chemical CO, USA). The organic solvent was methylene chloride (Labsynth Ltda., Brazil). Distilled water of Milli-Q quality was used. The model encapsulated drug was praziquantel (PRZ) (Henrifarma, Brazil). 


\section{Methods}

\section{Nanoparticles preparation}

The nanoparticles, loaded or not with praziquantel (PRZ), were prepared by an emulsion-solvent evaporation method. Typically, a solution of PLGA in a determined volume of methylene chloride containing or not PRZ (10-30\% $\mathrm{w} / \mathrm{w})$ was mixed with a $0.7 \%(\mathrm{w} / \mathrm{v})$ PVA aqueous solution. This mixture was homogenized for $1 \mathrm{~min}$ by vortex and then sonicated using a microtip probe sonicator set at $55 \mathrm{~W}$ of energy output (XL 2002 Sonicator $^{\circledR}$ ultrasonic liquid processor) during $20 \mathrm{~min}$ to produce the oil-in-water emulsion. The organic phase was evaporated during $20 \mathrm{~min}$ on a rotative evaporator under partial vacuum. The nanoparticles were recovered by ultracentrifugation $(21,000$ rpm, $25 \mathrm{~min}$, Hitachi). The nanoparticles were washed twice with water in order to remove traces of PRZ eventually adsorbed on the surface. The washing solutions were eliminated by a further centrifugation as described above. The purified nanoparticles were freeze-dried for $24 \mathrm{~h}$.

\section{Morphology}

The morphology of the nanoparticles was investigated by scanning electron microscopy (SEM) (JEOL JSM- T330A). The nanoparticles were fixed on supports and coated with gold under an argon atmosphere using a gold sputter module in a high-vacuum evaporator. Observation was performed by 10 and $20 \mathrm{kV}$.

\section{Determination of PRZ loading}

The amount of PRZ entrapped into the nanoparticles was determined in triplicate by HPLC with the UV detection set at $262 \mathrm{~nm}$ (Varian ProStar 330). A reversed phase Lichrospher $\mathrm{C} 18$ column $(240$ x $4 \mathrm{~mm}$ i.d., pore size $5 \mu \mathrm{m}$ ) was used. The mobile phase consisted of a mixture of acetonitrile:water $(3: 2 \mathrm{v} / \mathrm{v})$ and the flow rate was set at $1 \mathrm{ml} / \mathrm{min}$. The freeze-dried nanoparticles $(20 \mathrm{mg})$ were dissolved in methylene chloride $(5 \mathrm{~mL})$ (direct method) and vortexed for $15 \mathrm{~min}$. After eventual dilutions in mobile phase, the solution was injected and the drug concentration was obtained by means of a analytical curve previously constructed. Before injection, all solutions were previously filtered through a membrane filter (pore size $0.22 \mu \mathrm{m}$, Millipore).

\section{Differential Scanning Calorimetry (DSC)}

The physical state of PRZ inside the nanoparticles was characterized by the analysis of the DSC curves. The curves were obtained in a DSC cell (Mettler, SW 7.01) using aluminium crucibles with about $2 \mathrm{mg}$ of samples, under dynamic air atmosphere $(100 \mathrm{~mL} / \mathrm{min})$ and heating rate of $20^{\circ} \mathrm{C} / \mathrm{min}$ at a temperature range from 25 to $600^{\circ} \mathrm{C}$. DSC cell was calibrated with indium (m.p. $156,6^{\circ} \mathrm{C}$; AHfus $=$ $28,54 \mathrm{~J} / \mathrm{g}$ ) and zinc (m.p. $419.6^{\circ} \mathrm{C}$ ). DSC experiments with pure PRZ were previously carried out to identify the melting point peak. As a control, physical mixtures of PRZ and PLGA were also analyzed. Subsequently, nanoparticles with a theoretical loading rate of $10 \%$ of PRZ were analyzed, as required by the sensitivity of the apparatus.

\section{Simultaneous TG-DTA}

The thermal stability of the samples was verified by simultaneous TG and DTA, using a SDT 2960 system (TA INSTRUMENTS). TG-DTA curves were obtained in the temperature range from 30 to $800{ }^{\circ} \mathrm{C}$, using aluminium crucibles with about $8 \mathrm{mg}$ of samples, under dynamic air atmosphere $(100 \mathrm{~mL} / \mathrm{min})$ and heating rate of $20^{\circ} \mathrm{C} / \mathrm{min}$.

\section{Fourier Transform Infrared (FTIR) Studies}

Fourier transform infrared (FTIR, SHIMADZU, FTIR-8300) analysis was conducted to verify the occurrence of chemical bonds between drug and polymer. The samples were scanned in the IR range from 500 to $4000 \mathrm{~cm}^{-1}$ and carbon black was used as reference. The detector was purged carefully with clean dry helium gas to increase the signal level and reduce moisture.

\section{RESULTS AND DISCUSSION}

\section{Nanoparticles morphology}

The emulsion-solvent evaporation process produced nanoparticles successfully, as can be seen in Figure 1. The particles showed sub-micrometric size, fine spherical shape, without any aggregation or adhesion.

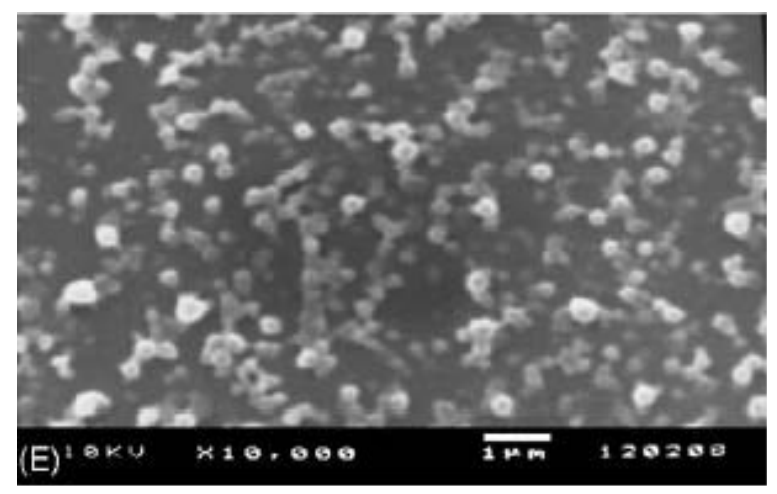

FIGURE 1 - SEM images of PRZ-nanoparticles.

\section{Determination of PRZ loading}

The incorporation of PRZ into PLGA nanoparticles 
was examined. Maintaining a constant initial mass polymer, the mass of PRZ was varied from 10 to $30 \%$ in relation to polymer mass. The encapsulation efficiency of the nanoparticles is illustrated in Table I. A direct relation between encapsulation efficiency and theoretical PRZ loading was not observed. As can be seen, the higher encapsulation ( $88 \%$ ) was obtained with a theoretical drug loading of $10 \%$.

TABLE I - Encapsulation efficiency of PRZ-loaded PLGA nanoparticles

\begin{tabular}{lc}
\hline $\begin{array}{l}\text { Theoretical amount } \\
\text { of PRZ (\% w/w) }\end{array}$ & $\begin{array}{l}\text { Encapsulation } \\
\text { efficiency }(\%)\end{array}$ \\
\hline 10 & $88 \pm 3$ \\
20 & $73 \pm 1.5$ \\
30 & $77 \pm 3.5$ \\
\hline
\end{tabular}

\section{Thermal analysis}

Figure 2 show DSC curves, which provided qualitative and quantitative information about the physical state of the drug in the nanoparticles and in the control samples, i. e. the pure drug and the physical mixture of PRZ and PLGA.

The pure PRZ (Curve B, Figure 2) shows a sharp endothermic peak that corresponds to melting at $143{ }^{\circ} \mathrm{C}$, indicating its crystalline nature. After melting (from $250{ }^{\circ} \mathrm{C}$ ), two exothermic peaks are observed due to the thermal decomposition of the drug, with maximum temperatures around 400 and $560{ }^{\circ} \mathrm{C}$. These data are confirmed by the TG-DTA curve of pure PRZ (Figure $3 \mathrm{D}$ ), which in addition shows that the maximum weight loss (99.99\%) occurs in $366^{\circ} \mathrm{C}$.

The pure PLGA exhibit an endothermic event $\left(60^{\circ} \mathrm{C}\right)$ referring to the relaxation peak that follow the glass transition (Curve A, Figure 2). No melting point was observed, because PLGA appears amorphous in nature. The exothermic peaks in 370,400 e $500^{\circ} \mathrm{C}$ are related to the thermal decomposition of the polymer. The decomposition, characterized by an endothermic event, has begun at approximately $320^{\circ} \mathrm{C}$. The TG-DTA curves of pure PLGA (Figure $3 \mathrm{~A}$ ) shows that the polymer presents thermal stability until $250{ }^{\circ} \mathrm{C}$. The weight loss of pure PLGA, attributed to thermal decomposition, occurs in two steps $\left(390{ }^{\circ} \mathrm{C}-96.60 \%\right.$ and $\left.470{ }^{\circ} \mathrm{C}-3.18 \%\right)$.

The DSC curves of PRZ and PLGA physical mixture (Curve C, Figure 2) showed peaks resulting from simple superposition of the DSC curves of the separated components. Thus, none interaction could be attributed to the heating process.
The relaxation peak of empty nanoparticles was the same of the pure PLGA $\left(60^{\circ} \mathrm{C}\right)$ (Curve D, Figure 2). The thermal decomposition of empty nanoparticles has begun in a lower temperature $\left(220^{\circ} \mathrm{C}\right)$ than that of the pure polymer $\left(320^{\circ} \mathrm{C}\right)$. The nanoparticles are more exposed to the thermal degradation because their sub-micrometric size makes the superficial area larger. In relation to the polymer, since the nanoparticles show wider superficial area they degrade easier. It was not observed an endothermic peak in approximately $350{ }^{\circ} \mathrm{C}$, that seem to be characteristic of PLGA (Curve A, Figure 2 and Curve C, Figure 2), confirming the previous data that shows PLGA nanoparticles to have lower thermal stability than pure polymer.

The DSC curve of PRZ-containing nanoparticles (Curve E, Figure 2) shows the event corresponding to the relaxation enthalpy of polymer $\left(60^{\circ} \mathrm{C}\right)$. It can be observed that the microencapsulation process did not affect the polymer structure because the pure polymer presented the same value for relaxation enthalpy. The thermal decomposition of PRZ-containing particles begins approximately at the same temperature as the empty particles $\left(200^{\circ} \mathrm{C}\right)$, but the exothermic event was more intense, because the decomposition refers to both polymer and drug. The DSC study did not detect any crystalline drug material in the PRZ-loaded nanoparticles samples; the endothermic peak of PRZ was absent. Thus, it can be concluded that the drug incorporated into the nanoparticles was in an amorphous or disordered-crystalline phase of a molecular dispersion or a solid solution state in the polymer matrix. In this case, the change in thermoanalytical profile indicates a strong interaction in function of the heating, attributed to drug dissolution in melted polymer. Similar results with others hydrophobic drugs encapsulated in PLGA matrix were obtained by others authors (VenierJulienne, Benoit, 1996; Mu, Feng, 2002; Fitzgerald, Corrigan, 1996).

The TG-DTA curves confirmed the data obtained by DSC. Both empty and drug containing nanoparticles present thermal stability in a lower temperature range $\left(200^{\circ} \mathrm{C}\right.$ ) compared with the pure polymer (Figure $3 \mathrm{~B}$ and $3 \mathrm{C}$, respectively). The nanoparticles are more reactive than the polymer due to their wider superficial area and, consequently, they suffer thermal decomposition more quickly. The weight loss of PRZ-nanoparticles occurs in two steps $\left(315^{\circ} \mathrm{C}-69.35 \%\right.$ and $\left.520^{\circ} \mathrm{C}-24.73 \%\right)$, associated with exothermic events between the temperatures of $200^{\circ} \mathrm{C}$ and $550^{\circ} \mathrm{C}$. The TG-DTA curve of PRZnanoparticles did not show any peak relative to the drug melting point. Such fact was also confirmed by DSC, reinforcing the idea that the drug were entrapped in the nanoparticles in an amorphous state. 


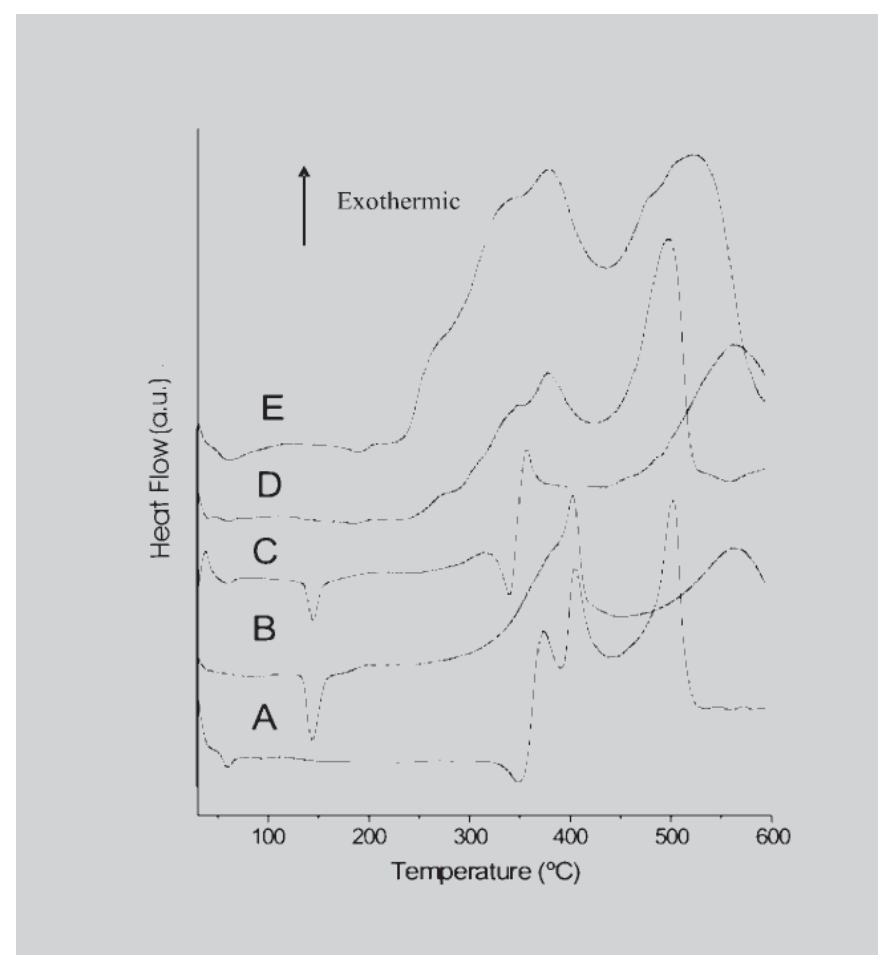

FIGURE 2 - DSC curves obtained in dynamic air atmosphere $(100 \mathrm{~mL} / \mathrm{min})$ and heating rate $20{ }^{\circ} \mathrm{C} / \mathrm{min}$ of samples: A) pure PLGA; B) pure PRZ; C) physical mixture PRZ/PLGA; D) empty nanoparticles and E) PRZ nanoparticles.
In the Figure 4, showing DSC curve of PRZnanoparticles, the thermal pattern of the sample in an initial time (first measure) is compared to that in the end time (4 months later, the sample was stored at room temperature). Thermal changes were not observed during the period of the time studied. This study suggests that no interaction that could interfere in polymer and drug structure at the time observed. In conclusion, no strong chemical interaction between drug and polymer was observed. The nanoparticles could be stored in room temperature with security.

\section{Fourier Transform Infrared Studies (FTIR)}

FTIR analysis measures the selective absorption of light by the vibration modes of specific chemical bonds in the sample. The observation of vibration spectrum of encapsulated drug allows evaluating the kind of interaction occurring between the drug and polymer, because the vibrations of the atoms involved in this interaction can suffer alterations in frequency and intensity (Silverstein et al., 1994).

In the present work, one batch of prepared PRZnanoparticles, pure PLGA, pure PRZ and physical mixture of PLGA and PRZ were submitted to FTIR and the spectra obtained are showed in Figure 5. The pure PRZ sample (Figure $5 \mathrm{~B}$ ) showed the main peaks contributed by the functional groups of molecule such as

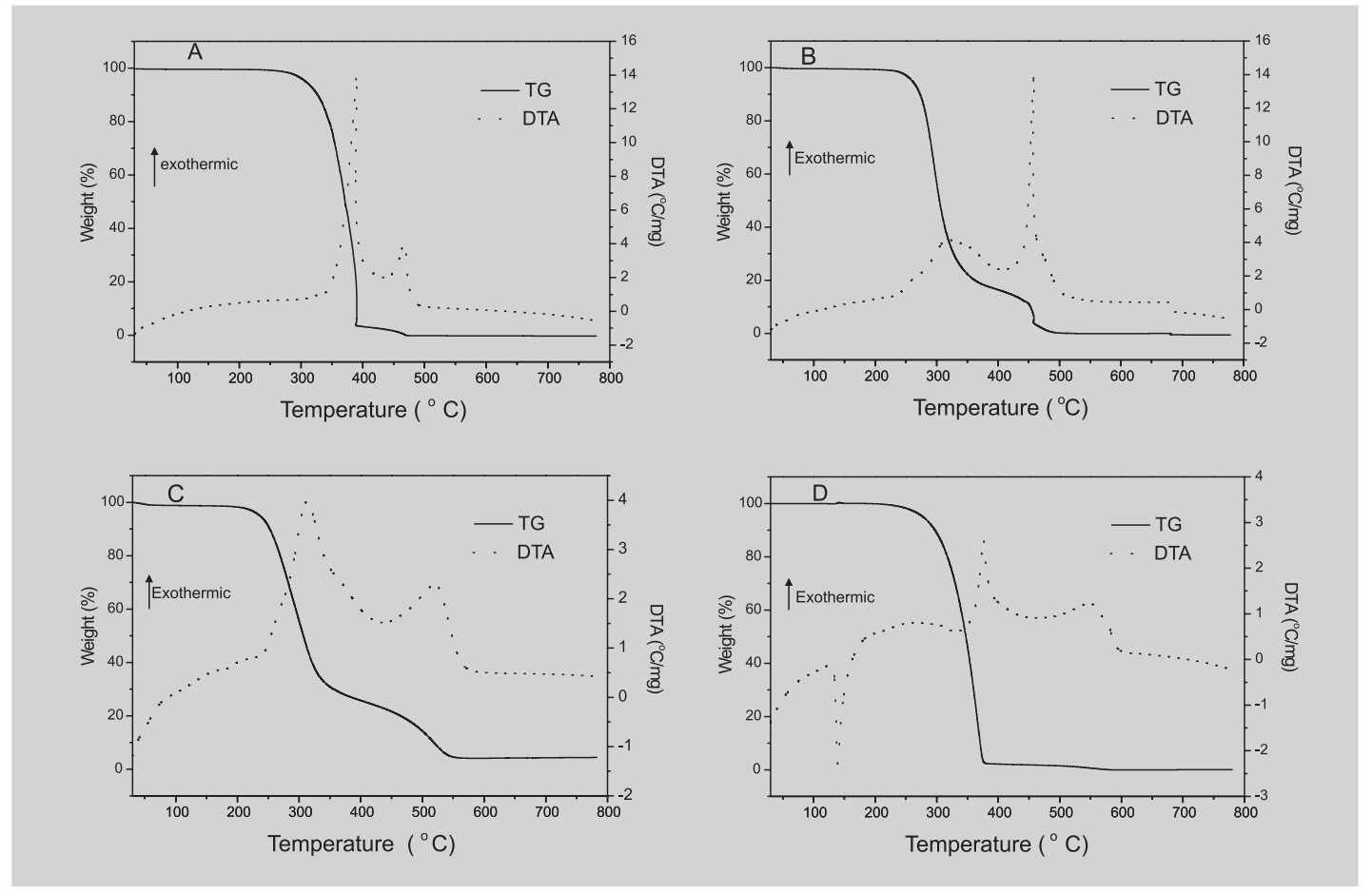

FIGURE 3 - TG-DTA curves obtained in dynamic air atmosphere $(100 \mathrm{~mL} / \mathrm{min})$ and heating rate $20^{\circ} \mathrm{C} / \mathrm{min}$ of samples: A) pure PLGA; B) empty nanoparticles; C) PRZ nanoparticles and D) pure PRZ. 


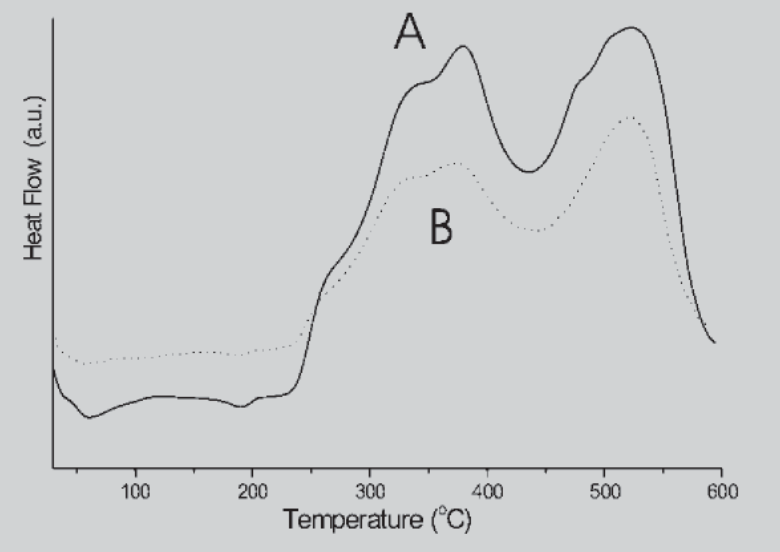

FIGURE 4 - DSC curves obtained in dynamic air atmosphere $(100 \mathrm{~mL} / \mathrm{min})$ and heating rate of $20^{\circ} \mathrm{C} / \mathrm{min}$ of PRZ nanoparticles: A) sample recently prepared; B) sample stored for four months.

carbonyl $-\mathrm{C}=\mathrm{O}$ stretching $\left(1630 \mathrm{~cm}^{-1}\right),-\mathrm{CH},-\mathrm{CH}_{2},-\mathrm{CH}_{3}$ stretching (2900-3000 $\left.\mathrm{cm}^{-1}\right),-\mathrm{C}-\mathrm{N}$ stretching (1000$1350 \mathrm{~cm}^{-1}$ ). The pure PLGA sample (Figure $5 \mathrm{~A}$ ) showed peaks such as $-\mathrm{CH},-\mathrm{CH}_{2},-\mathrm{CH}_{3}$ stretching (2850-3000 $\left.\mathrm{cm}^{-1}\right)$, carbonyl $-\mathrm{C}=\mathrm{O}$ stretching $\left(1700-1800 \mathrm{~cm}^{-1}\right), \mathrm{C}-\mathrm{O}$ stretching (1050-1250 $\mathrm{cm}^{-1}$ ), and -OH stretching (3200$3500 \mathrm{~cm}^{-1}$ ), which were broad. The physical mixture (Figure $5 \mathrm{C}$ ) and PRZ-loaded nanoparticles (Figure $5 \mathrm{D}$ ) showed peaks resulting from simple superposition of their separated components in the infrared spectra. In the region of low wavelength the peaks cannot be so perfectly observed because of the low drug concentration in the nanoparticles. The spectral analysis indicated that the specific functional groups of polymeric material in the nanoparticles surface have almost the same chemical characteristics of the pure polymer and the drug entrapped shows their main characteristics peaks. The study suggests that did not occur molecular interactions that could alter the chemical structure of the drug in the time of study.

\section{CONCLUSIONS}

The $\mathrm{T}_{\mathrm{g}}$ of PLGA is above the physiological temperature of $37^{\circ} \mathrm{C}$ and hence it is glassy in nature. Thus, they have a fairly rigid chain structure, which gives significant mechanical strength usefull to drug delivery devices.

The thermoanalytical study suggests that PRZ is in an amorphous state or in disordered crystalline phase of a molecular dispersion in the PLGA polymeric matrix. The relaxation enthalpy of PLGA was not influenced by the

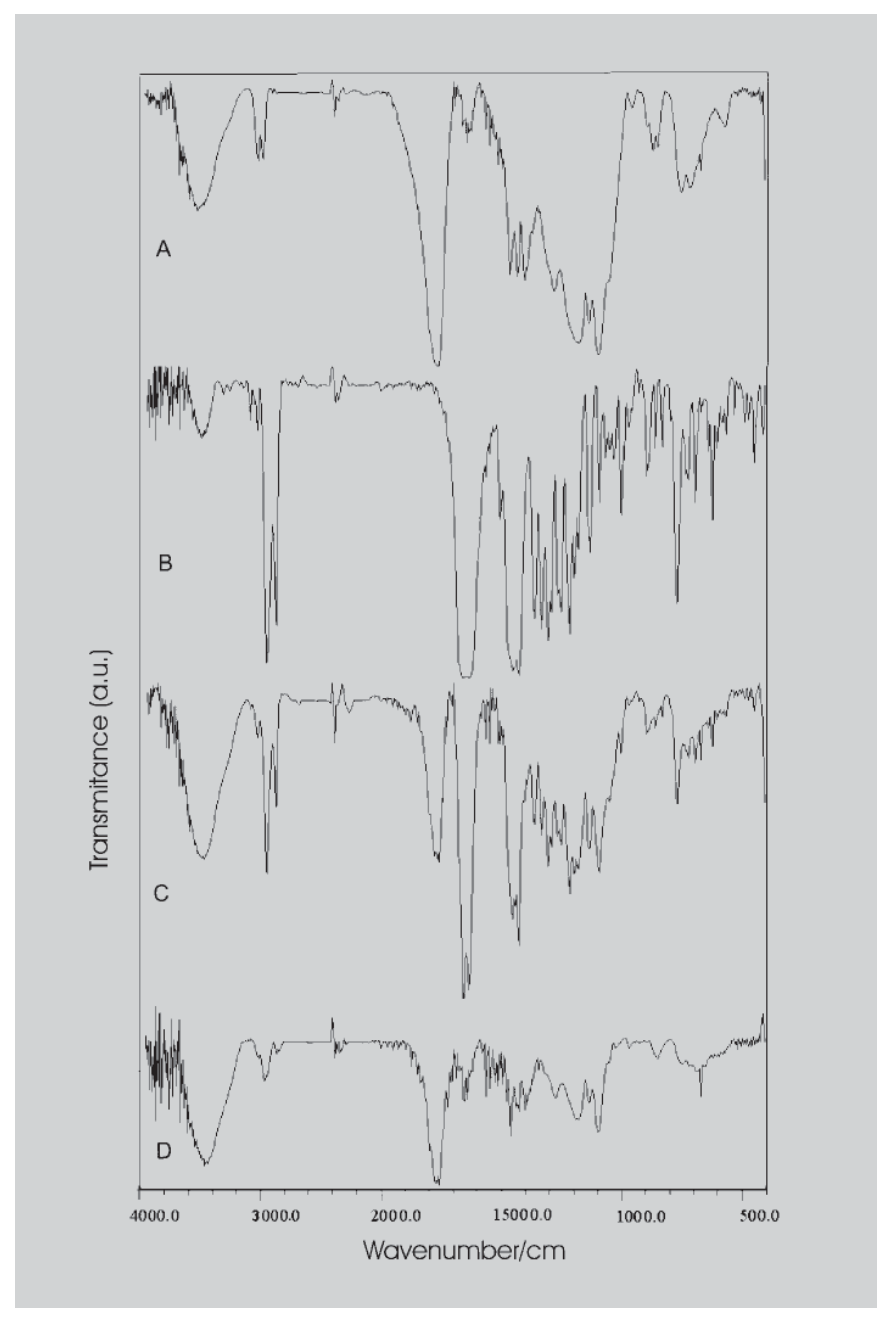

FIGURE 5 - Infrared spectra of: A) pure PLGA; B) pure PRZ; C) physical mixture PRZ/PLGA and D) PRZ nanoparticles.

procedure used. The thermal stability was evaluated, and since that all materials analyzed did not suffered appreciable decomposition below $200^{\circ} \mathrm{C}$ in the analytical conditions used, it can be suggested that they can be safely processed using some thermal treatment. The thermoanalytical results corroborated the infrared studies, showing that strong chemical interactions between PLGA and PRZ did not occur, in the length of time studied. According to that, all results obtained suggested that the microencapsulation process did not interfere with the chemical structure of the polymer and keeps the structural drug integrity. Thus, the methods employed to produce and to characterize samples seem to be adequate.

\section{ACKNOWLEDGEMENTS}

The authors gratefully acknowledge the financial support of the Brazilian research financing institution CAPES. 


\section{RESUMO}

\section{Estudo termoanalítico de nanopartículas de PLGA contendo praziquantel}

Nanoparticulas poliméricas têm recebido grande atenção como potenciais sistemas de liberação controlada de fármacos. Polímeros biodegradáveis são extensivamente usados no desenvolvimento destes sistemas e os poliésteres como ácido poli-láctico e o glicólico, e seus copolímeros, como o ácido poli(láctico-co-glicólico) são os mais usados considerando sua biocompatibilidade e biodegradação. Técnicas de análise térmicas são usadas para substâncias farmacêuticas há mais de 30 anos e são métodos rotineiros para investigação de interações fármaco-excipiente. O objetivo deste trabalho é usar análise térmica para caracterizar nanopartículas de PLGA contendo um fármaco hidrofóbico, o praziquantel. Os resultados mostram que o fármaco apresenta-se em estado amorfo ou em fase cristalina desordenada de dispersão molecular na matriz polimérica e que o processo de microencapsulação não interfere na estrutura química do polímero e manteve a integridade estrutural do fármaco.

UNITERMOS: Nanopartículas. Praziquantel. PLGA. DSC. TG-DTA. Espectroscopia no infravermelho.

\section{REFERENCES}

ALLEMANN, E.; LEROUX, J.C.; GURNY, R. Polymeric nano- and microparticles for the oral delivery of peptides and peptidomimetics. Adv. Drug Del. Rev., v. 34, p. 171$189,1998$.

ANDERSON, J.M.; SHIVE, M.S. Biodegradation and biocompatibility of PLA and PLGA microspheres. $A d v$. Drug Del. Rev., v. 28, p. 5-24, 1997.

ARAÚJO, A.S.; STORPIRTIS, S.; MERCURI, L.P.; CARVALHO, F.M.S; SANTOS FILHO, M.; MATOS, J.R. Thermal analysis of the antiretroviral zidovuine (AZT) and evaluation of the compatibility with excipients used in solid dosage forms. Int. J. Pharm., v. 260, p. 303-314, 2003.

BEISER, I.H.; KANAT, I.O. Biodegradable internal fixation. A literature review. J. Am. Podiatric. Med. Assoc, v. 80, p. $72-75,1990$.

BURKERSRODA, F.V.; SCHEDL, L.; GÖPFERICH, A. Why degradable polymers undergo surface erosion or bulk erosion. Biomaterials, v. 23, p. 221-231, 2002.
CALVO, P.; VILA-JATO, J. L.;ALONSO, M. J. Comparative in vitro evaluation of several colloidal systems, nanoparticles, nanocapsules, and nanoemulsions, as ocular drug carriers. J. Pharm. Sci., v. 85, p. 530-536, 1996.

CANEVAROLO, S.V. Ciências dos polímeros. São Paulo: Artliber, 2002. 183p.

DUMITRIU, S. Polymeric biomaterials. New York: Marcel Dekker, 1996. 450p.

FITZGERALD, J.F.; CORRIGAN, O.I. Investigation of the mechanisms governing the release of levamisole from poly-lactide-co-glycolide delivery systems. J. Control. Release, v. 42, p. 125-132, 1996.

FORD, J.L; TIMMINS, P. Pharmaceutical thermal analysis: technique and applications. New York: Wiley-Interscience, 1986. 380p.

GAMISANS, F.; LACOULONCHE, F.; CHAUVET, A.; ESPINA, M.; GARCIA, M.L.; EGEA, M.A. Flurbiprofen-loaded nanospheres: analysis of the matrix structure by thermal methods. Int. J. Pharm., v. 179, p. 3748, 1999.

GÖRNER, T.; GREF, R.; MICHENOT, D.; SOMMER, F.; TRAN, M.N.; DELLACHERIE, E. Lidocaine-loaded biodegradable nanospheres. I. Optimization of the drug incorporation into the polymer matrix. J. Control. Release, v. 57, p. 59-268, 1999.

HANS, M.L; LOWMAN, A.M. Biodegradable nanoparticles for drug delivery and targeting. Curr. Opin. Sci., v. 6, p. 319-327, 2002.

HAUSBERG, A.G.; DELUCA, P.P. Characterization of biodegradable poly (lactide-co-glycolide) polymers and microspheres. J. Pharm. Biomed. Anal., v. 13, p. 747-760, 1995.

HOLLAND, S.J.; YASIN, M. Polymers for biodegradable medical devices. 1 . The potential of polyesters as controlled macromolecular release systems. J. Control. Release, v. 4, p. 155-180, 1986.

IANNACE, S.; AMBROSIO, L.; HUANG, S.J.; NICOLAIS, L. Poly(3-hydroxybutyrate)-co-(3-hydroxyvalerate)/ Poly-L-lactide blends: thermal and mechanical properties. J. Appl. Polym. Sci., v. 54, p. 1525-1530, 1994. 
JAIN, R.A. The manufacturing techniques of various drug loaded biodegradable poly (lactide-co-glicolide) (PLGA) devices. Biomaterials, v. 21, p. 2475-2490, 2000.

LANGER, R.; CIMA, L.G.; TAMADA, J.A.; WINTERMANTEL, E. Future directions in biomaterials. Biomaterials, v. 11, p. 738-745, 1990.

LINDHARDT R. Biodegradable polymers for controlled release of drugs. New York: Springer-Verlag, 1998. 410p.

MAGENHEIM, B.; BENITA; S. Nanoparticle characterization: a comprehensive physicochemical. approach. S.T.P. Pharma Sci.,v.1, p. 221-227, 1991.

MAINARDES, R.M.; EVANGELISTA, R.C. PLGA nanoparticles containing praziquantel: effect of formulation variables on size distribution. Int. J. Pharm, v. 290, p. 137-144, 2005.

MAINARDES, R.M.; SILVA, L.P. Drug delivery systems: past, present and future. Curr. Drug Targets, v. 5, p. 389406, 2004.

MU,L.; FENG, S.S. Vitamin E TPGS used as emulsifier in the solvent evaporation/extraction technique for fabrication of polymeric nanospheres for controlled release of paclitaxel (Taxol Ò). J. Control. Release, v. 80, p. 129-144, 2002.

PANYAM, J.; LABHASETWAR, V. Biodegradable nanoparticles for drug and gene delivery to cells and tissue. Adv. Drug Del. Rev., v. 55, p. 329-347, 2003.

SCHAFFAZICK, S.R.; GUTERRES, S.T.; FREITAS, L.L.; POHLMANN, A.R. Caracterização e estabilidade físicoquímica de sistemas poliméricos nanoparticulados para administração de fármacos. Quim. Nova, v.26, p. 726737, 2003.
SILVERSTEIN, R.M.; BASSLER, G.C.; MORRIL, T.C.; Identificação espectrométrica de compostos orgânicos. Rio de Janeiro: LTC editora, 1994, 360p.

SOPPIMATH, K.S.; AMINABHAVI, T.M.; KULKARNI, A.R.; RUDZINSKI, W.E. Biodegradable polymeric nanoparticles as drug delivery devices. J. Control. Release, v. 70, p. 1-20, 2001.

UHRICH, K.E.; CANNIZZARO, S.M.; LANGER, R.S.; SHAKESHELF, K.M. Polymeric systems for controlled drug release. Chem. Rev., v. 99, p. 3181-3198, 1999.

VENIER-JULIENNE, M.C.; BENOIT, J.P. Preparation, purification and morphology of polymeric nanoparticles as drug carriers. Pharma Acta Hel., v. 71, p. 121-128, 1996.

MARINI, A.;BERBENNI, V.;BRUNI, G.;COFRANCESCO, P.;GIORDANO, F.; VILLA, M. Physico-Chemical Characterization of drugs and drug forms in the solid state. Cur. Med. Chem: Anti-Infec. Agents, v.2, p. 303-321, 2003.

VERT, M.; LI, S.; GARREAU, H. Something new in the field of PLA/GA bioresorbable polymers? J. Control. Release, v. 16, p. 15-26, 1991.

VERT, M.; SCHWACH, G.; ENGEL, R.; COUDANE, J. Something new in the field of PLA/GA bioresorbable polymers? J. Control. Release, v. 53, p. 85-92, 1998.

Recebido para publicação em 28 de novembro de 2005 Aceito para publicação em 24 de novembro de 2006 